\title{
Mantle wedge serpentinization effects on slab dips
}

\author{
Eh Tan *
}

Institute of Earth Sciences, Academia Sinica, Taipei City, Taiwan

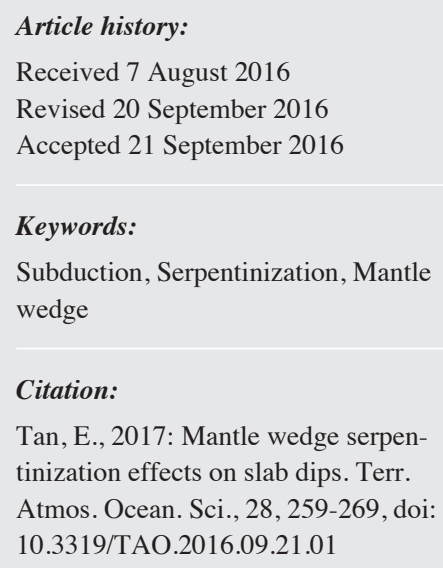

Tan, E., 2017: Mantle wedge serpentinization effects on slab dips. Terr. Atmos. Ocean. Sci., 28, 259-269, doi: 10.3319/TAO.2016.09.21.01

\begin{abstract}
The mechanical coupling between a subducting slab and the overlying mantle wedge is an important factor in controlling the subduction dip angle and the flow in mantel wedge. This paper investigates the role of the amount of mantle serpentinization on the subduction zone evolution. With numerical thermos-mechanical models with elasto-visco-plastic rheology, we vary the thickness and depth extent of mantle serpentinization in the mantle wedge to control the degree of coupling between the slab and mantle wedge. A thin serpentinized mantle layer is required for stable subduction. For models with stable subduction, we find that the slab dip is affected by the down-dip extent and the mantle serpentinization thickness. A critical down-dip extent exists in mantle serpentinization, determined by the thickness of the overriding lithosphere. If the down-dip extent does not exceed the critical depth, the slab is partially coupled to the overriding lithosphere and has a constant dip angle regardless of the mantle serpentinization thickness. However, if the down-dip extent exceeds the critical depth, the slab and the base of the overriding lithosphere would be separated and decoupled by a thick layer of serpentinized peridotite. This allows further slab bending and results in steeper slab dip. Increasing mantle serpentinization thickness will also result in larger slab dip. We also find that with weak mantle wedge, there is no material flowing from the asthenosphere into the serpentinized mantle wedge. All of these results indicate that serpentinization is an important ingredient when studying the subduction dynamics in the mantle wedge.
\end{abstract}

\section{INTRODUCTION}

Subduction of the oceanic plate into the mantle is the major driving force of plate tectonics (Forsyth and Uyeda 1975; Conrad and Lithgow-Bertelloni 2002) and the major source to introduce thermal and chemical heterogeneity into the mantle (Hacker et al. 2003). The negative buoyancy of cold oceanic lithosphere, contrasting with the underlying warm mantle, provides sufficient force to pull the entire plate down. Complicated physical and chemical processes occur in the subduction zones (Van Keken and King 2005). The subducted oceanic crust carries water with it in the form of hydrated minerals into the mantle. As the oceanic crust sinks through the mantle, its temperature and pressure gradually increase. The hydrated minerals move out of their stability fields and transform into less hydrated or anhydrated minerals (Ulmer and Trommsdorff 1995; Hacker et al. 2003). Water is released during these metamorphic process-

\footnotetext{
* Corresponding author

E-mail:tan2@earth.sinica.edu.tw
}

es. The released water will migrate upward into the mantle wedge and hydrate the overlying mantle peridotite through a serpentinization process (Hacker et al. 2003). Serpentinized peridotite is much weaker than its anhydrated counterpart (Escartín et al. 2001). The serpentinized mantle wedge becomes weaker than normal mantle as a result.

Receiver function study has found inverted velocity contrast in Cascadia forearc mantle, which is interpreted as mantle serpentinization (Bostock et al. 2002). This interpretation is further supported by seismic tomography (Ramachandran et al. 2005) and magnetic survey (Blakely et al. 2005). Tomographic seismic velocity models show that the outer wedge of north-eastern Japan subduction zone may consist of relatively cool, serpentinized mantle that is stagnant, whereas the rest of the mantle wedge is engaged in corner flow (Yamamoto et al. 2013). Receiver function analyses (Tibi et al. 2008; Nikulin et al. 2009) have also found evidence of a distinct low seismic velocity layer on top of the down-going oceanic plate in the mantle wedge, which 
is consistent with a layer of serpentinized peridotite above the subducted oceanic crust. Joint seismic tomography in westernmost Ryukyu subduction zone has found high $\mathrm{Vp} /$ Vs anomaly, possibly serpentinized mantle, at $30-80 \mathrm{~km}$ depth (Chou et al. 2009). These observations suggest that mantle wedge serpentinization is prevalent or even ubiquitous. However, the thickness of serpentinized peridotite in the mantle wedge is still ill-constrained due to sparse observations above the plate boundary (Nikulin et al. 2009).

Numerous numerical models with hydration and serpentinization in the subduction have been presented in the past. Hyndman and Peacock (2003) computed the thermal structure of several subduction zones using a corner flow model. They estimated the amount of water released from down going oceanic crust and sediment dehydration. They argued that the water flux is large enough so that the forearc mantle must be serpentinized. Manea et al. (2005) investigated the thermos-mechanical structure of the Central Mexico subduction zone. Their model indicated that slab dehydration occurs at depths between 40 and $60 \mathrm{~km}$ and that the Central Mexico Volcanic Belt location is consistent with the migration trajectory of melts. Iwamori et al. (2007) modelled the generation and transportation of volatile and melt and found that episodic subduction of young slabs and ridges can explain the heat source for generating a large amount of granitic magmas of batholiths in eastern Asia. Wada et al. (2008) explored the effect of the degree of coupling between the slab and mantle wedge on the thermal structure in mantle wedge. They found that a weak coupling will result in a stagnant forearc mantle wedge and decrease the temperature there, which provides a stable environment for serpentinite formation. In all of the aforementioned studies, the hydration process is calculated a posterior after the flow and temperature calculation. When the mantle is serpentinized, its low viscosity significantly changes the flow pattern and affects the temperature structure (Van Keken 2003), which in turn affects the serpentinite formation. Arcay et al. (2005) considered this feedback between hydration, flow and temperature in their models. They found that thermal erosion on the base of overriding lithosphere is enhanced when the viscosity is strongly reduced in hydrated rocks. Gerya and Yuen (2003) incorporated hydration front migration into a thermo-mechanical model. They found that the water transport and melting can trigger buoyant Rayleigh-Taylor instability from the hydrated layer on top of the slab. Angiboust et al. (2012) further solved for the porous fluid flow of dehydration coupled with thermos-mechanical model. They found that fluid circulation could induce downward water filtration, which promotes oceanic crust detachment at the subduction interface. All of these results indicate that hydration and serpentinization are important ingredients when studying subduction zone and mantle wedge dynamics.

The corner flow in the mantle wedge will generate a slab suction force (Tovish et al. 1978). A low viscosity man- tle wedge will reduce the suction force in dynamic models (Billen and Gurnis 2001). The suction force, the negative slab buoyancy, the plate bending resistance force, and the slab sinking resistance force are balanced dynamically. The force balance affects the slab geometry, which is manifested as the slab dip angle. The subducted slab dip can be inferred from the seismic Wadati-Benioff zone. Several studies attempted to relate subduction zone slab dips to other subduction zone geometric parameters and physical properties (Jarrard 1986; Lallemand et al. 2005; Syracuse and Abers 2006; Heuret et al. 2011). The results indicate that the age of the plate at the trench, the convergence velocity and the stress state of the overriding plate do not correlate well with slab dips. Slab dip tends to be larger if the overriding plate is oceanic rather than continental (Lallemand et al. 2005). A better correlation exists for the slab dip at shallow depth $(<50 \mathrm{~km})$ and the sediment thickness at the trench (Tan et al. 2012). Gerya and Meilick (2011) found that high pore pressure, i.e., low effective friction coefficient, will lead to shallow slab dip. Using numerical models with elastovisco-plastic rheology, Tan et al. (2012) found that the slab dip at shallow depth is controlled mainly by the frictional strength of the sediment and serpentinite, which constitute the subduction interface. Models with low friction sediment and serpentinite will form a broad accretionary prism. The accretionary prism is composed mostly of sediment and original forearc material and thus also has low frictional strength. The basal slope of the accretionary prism, i.e., the upper interface of the subducted slab, is stressed under Coulomb failure and maintains a shallow dip as predicted by critical wedge theory (Suppe 1981; Dahlen et al. 1984).

The effect of mantle wedge serpentinization thickness on slab dip is subtler. Tan et al. (2012) found that when the frictional strength of sediment and serpentinite is high, a thicker layer of serpentinized peridotite will result in larger slab dip. They argued that when the serpentinized mantle layer is thick, the subducted slab is more decoupled from the mantle wedge. The negative slab buoyancy dominates the resistive forces. As a result, the slab will have a steeper dip. However, Tan et al. (2012) also found that when the frictional strength of the sediment and serpentinite is low, the slab dip is insensitive to the mantle wedge serpentinization thickness. Tan et al. (2012) does not provide an explanation for the insensitivity. We will explore the effect of mantle wedge serpentinization on the subduction in more detail and investigate why serpentinization thickness does not affect the slab dip as discussed in a previous study.

\section{METHODOLOGY}

Our numerical code geoFLAC uses the Fast Lagrangian Analysis of Continua (FLAC) technique (Cundall 1989). The detailed algorithm is presented elsewhere (Poliakov et al. 1993; Lavier et al. 2000; Tan et al. 2012) and will be only 
briefly described here. The equation of motion with elastovisco-plastic rheology is solved explicitly on a finite-element, Lagrangian grid. The elastic wave is strongly damped to quickly achieve quasi-static equilibrium. The stresses due to Maxwell elasto-viscous and Mohr-Coulomb elasto-plastic deformation are computed on each element. The lesser of the stress second invariants (effective stress) is taken as the final stress of the element. The elastic rheology assumes that the incremental strain and incremental stress obey the linearized Hooke's law with a bulk modulus $K_{S}=50 \mathrm{GPa}$ and shear modulus $G=30 \mathrm{GPa}$. The viscosity $\eta$ is nonNewtonian based on dislocation creep laws from laboratory experiments (Chen and Morgan 1990):

$\eta=\frac{1}{4}\left(\frac{4}{3 A}\right)^{\frac{1}{n}} \dot{\varepsilon}_{I I}^{\frac{1-n}{n}} \exp \left[\frac{E}{n R(T+273)}\right]$

where $n$ is the stress exponent, $A$ is the viscosity pre-exponent, $\dot{\varepsilon}_{I I}$ is the second invariant of the deviatoric strain rate tensor, $E$ is activation energy, $R$ is the universal gas constant, and $T$ is temperature in Celsius. The minimum viscosity is set to $10^{20} \mathrm{~Pa} \cdot \mathrm{s}$ to save computation time. Our test indicates that setting the minimum viscosity to lower values will not qualitatively affect the result. For plastic rheology, we use the Mohr-Coulomb law:

$\tau_{\text {yield }}=C+\sigma_{n} \tan \phi$

where $\tau_{\text {yield }}$ is the shear stress at yield, $C$ is the cohesion, $\sigma_{n}$ is normal stress and $\phi$ is the friction angle. Both the cohesion and friction angle are subjected to strain weakening and will decrease linearly with the amount of plastic strain $\varepsilon_{p l}$ from their initial values up to their saturation values, when $\varepsilon_{p l} \geq 0.1$. The different rock type parameters are listed in Table 1 . The lowest friction angle used is $5^{\circ}$, corresponding to a coefficient of friction 0.087 . Friction coefficient lower than 0.1 is commonly used in numerical models for subduction interface (Hassani et al. 1997; Hall et al. 2003; Gurnis et al. 2004; Sobolev and Babeyko 2005; Gorczyk et al. 2007; Kaus et al. 2008; Faccenda et al. 2009). The code also solves the equation of heat, which contains the thermal diffusion and frictional heating effects. We use constant coefficient of thermal expansion $\left(3 \times 10^{5} \mathrm{~K}^{-1}\right)$, thermal conductivity $\left(3.0 \mathrm{~W} \mathrm{~m}^{-1} \mathrm{~K}^{-1}\right)$, and heat capacity $\left(10^{3} \mathrm{~J} \mathrm{~kg}^{-1} \mathrm{~K}^{-1}\right)$ for all rock types.

The hydration-dehydration serpentinization and basalt metamorphic reactions are modelled with simplified phase diagrams (Tan et al. 2012). The oceanic crust will dehydrate into eclogite with suitable temperature $\mathrm{T}$ and pressure P conditions (Hacker 1996). The dehydration of down-going oceanic crust will release water to hydrate and serpentinize the overlying mantle wedge (Peacock 1996). We assume that mantle serpentinization will cease once the basalt-eclogite transformation is completed in some models. In other models, we will relax the assumption to allow hydration at deeper depth (discussed later). We do not include the thermodynamics and kinematics of mineral hydration nor the dynamics of porous flow. Instead, we parameterize the hydration process by instantaneously transforming the mantle wedge peridotite into serpentinized peridotite up to a finite thickness $H_{\text {serp }}$ above the subducted oceanic crust. The serpentine stability field is taken from Ulmer and Trommsdorff (1995). Serpentine is known to have a very weak creep rheology (Hilairet et al. 2007) and a low density. Therefore, the amount of serpentinization in the mantle wedge can significantly affect the stress state and temperature structure in the subduction zone. Additionally, the subducted sediment will transform into schist under high P-T conditions (Nichols et al. 1994).

The computation domain is $960 \mathrm{~km}$ wide and $300 \mathrm{~km}$ thick and divided into $186 \times 65$ rectangular elements. The initial configuration is plotted in Fig. 1. An oceanic plate spans the left $400 \mathrm{~km}$ of the domain. The oceanic crust is $7 \mathrm{~km}$ thick and overlain by $0.5 \mathrm{~km}$ of sediment layer. The grid spacing is refined near the surface and the middle of the

Table 1. Rock parameters used in the models (Kirby and Kronenberg 1987; Chen and Morgan 1990; Ranalli 1995).

\begin{tabular}{|c|c|c|c|c|c|c|c|}
\hline Rock Type & $\begin{array}{c}\text { Overriding } \\
\text { crust }\end{array}$ & $\begin{array}{c}\text { Oceanic crust, } \\
\text { basalt }\end{array}$ & $\begin{array}{c}\text { Subducted oceanic } \\
\text { crust, eclogite }\end{array}$ & $\begin{array}{c}\text { Mantle, } \\
\text { peridotite }\end{array}$ & $\begin{array}{c}\text { Serpentinized mantle } \\
\text { peridotite }\end{array}$ & Sediments & $\begin{array}{c}\text { Dehydrated sediments, } \\
\text { schist }\end{array}$ \\
\hline Density $\left(\mathrm{kg} \mathrm{m}^{-3}\right)$ & 2900 & 2880 & 3480 & 3300 & 3200 & $2400-2800^{*}$ & 2900 \\
\hline$n$ & 3.05 & 3.05 & 3.05 & 3 & 3 & 3 & 3 \\
\hline$A\left(\mathrm{MPa}^{-\mathrm{n}} \mathrm{s}^{-1}\right)$ & $1.25 \times 10^{-1}$ & $1.25 \times 10^{-1}$ & $1.25 \times 10^{-1}$ & $7 \times 10^{4}$ & $7 \times 10^{4}$ & $5 \times 10^{2}$ & $7 \times 10^{4}$ \\
\hline$E\left(\mathrm{~J} \mathrm{~mol}^{-1}\right)$ & $5.76 \times 10^{5}$ & $3.76 \times 10^{5}$ & $4.5 \times 10^{5}$ & $5.2 \times 10^{5}$ & $1.2 \times 10^{5}$ & $2 \times 10^{5}$ & $3.76 \times 10^{5}$ \\
\hline$C(\mathrm{~Pa})$, initial & $4 \times 10^{7}$ & $4 \times 10^{7}$ & $4 \times 10^{7}$ & $4 \times 10^{7}$ & $4 \times 10^{6}$ & $4 \times 10^{6}$ & $4 \times 10^{7}$ \\
\hline$C(\mathrm{~Pa})$, saturated & $4 \times 10^{6}$ & $4 \times 10^{6}$ & $4 \times 10^{6}$ & $4 \times 10^{6}$ & $4 \times 10^{6}$ & $4 \times 10^{6}$ & $4 \times 10^{6}$ \\
\hline$\phi\left(^{\circ}\right)$, initial & 30 & 30 & 30 & 30 & 5 & 5 & 30 \\
\hline$\phi\left({ }^{\circ}\right)$, saturated & 15 & 15 & 15 & 15 & 5 & 5 & 15 \\
\hline
\end{tabular}

Note: *: The density of sediments increases linearly from $2400 \mathrm{~kg} \mathrm{~m}^{-3}$ at the surface to $2800 \mathrm{~kg} \mathrm{~m}^{-3}$ below $6 \mathrm{~km}$ depth due to compaction. 

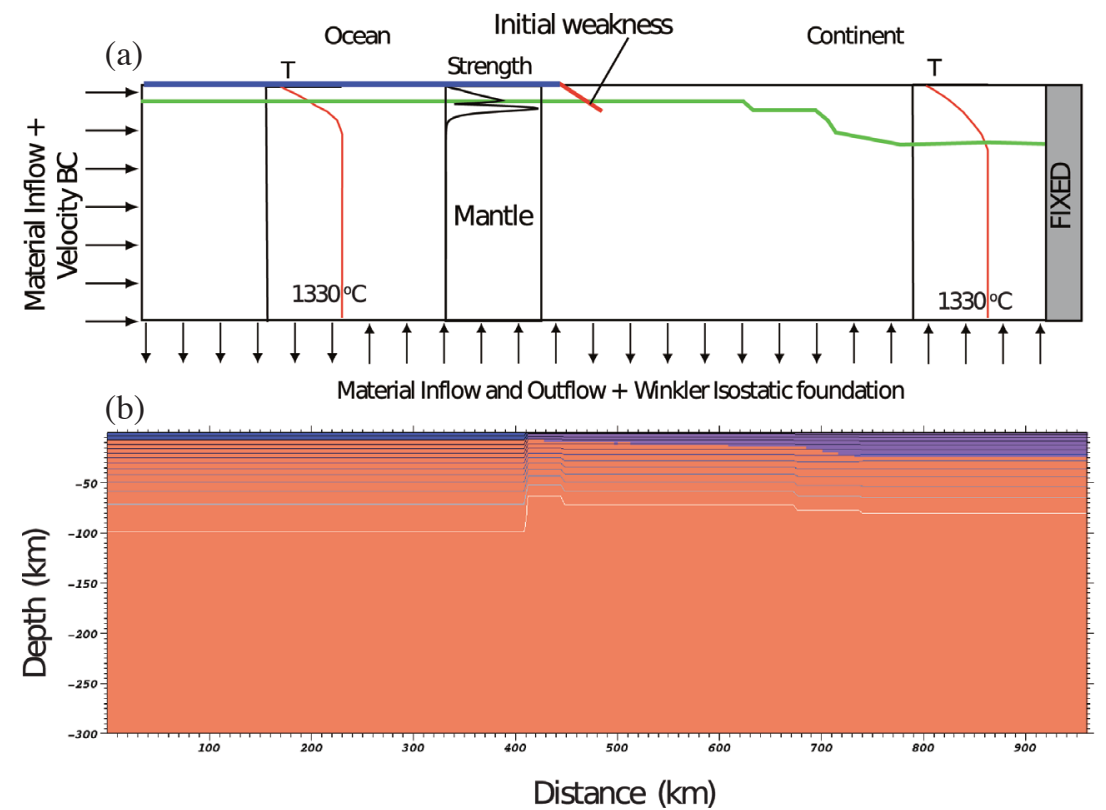

Fig. 1. Initial conditions. (a) Schematic representation of the model initial and boundary conditions (not to scale). (b) Rock types and temperature contours at $100^{\circ} \mathrm{C}$ intervals. Orange is the mantle peridotite, blue is the basaltic crust, and purple is the upper plate crust. Modified from Tan et al. (2012). (Color online only)

domain (where subduction will develop), with the finest grid spacing $4 \mathrm{~km}$ in the $\mathrm{x}$ direction and $1.5 \mathrm{~km}$ in the $\mathrm{z}$ direction. A few models with higher grid resolution $(1.6 \mathrm{~km})$ in the $\mathrm{x}$ direction are performed for cases of thin serpentinized mantle layer. Additionally, nearly one million markers (initially 9 per elements) were used to track the material, which allows us to represent a sediment layer $0.5 \mathrm{~km}$ thick. The oceanic plate has a thermal profile corresponding to the 60-Myrs half space cooling model. The rest of the domain is covered by a continental block. The continental crust adjacent to the oceanic plate is $7.5 \mathrm{~km}$ thick and gradually thickens to $25 \mathrm{~km}$ at the right boundary. The continental block has a thermal age that gradually increases from $30 \mathrm{Myrs}$ at the margin to $60 \mathrm{Myrs}$ at the right boundary. A slant weak zone with large plastic strain is placed at the plate boundary from the surface to $30 \mathrm{~km}$ depth with $18^{\circ}$ dip angle to facilitate subduction.

The left boundary is moving to the right at a constant velocity of $5 \mathrm{~cm} \mathrm{yr}^{-1}$, while the right boundary is fixed horizontally. Both boundaries can move freely in the $\mathrm{z}$ direction. The top is a free surface. Loading from the weight of the ocean is applied to nodes below sea level $(0 \mathrm{~m})$. The bottom boundary is a Winkler foundation, which is supported by inviscid fluid and open to inflow and outflow. The temperature boundary condition is $10^{\circ} \mathrm{C}$ at the top, $1330^{\circ} \mathrm{C}$ at the bottom, with no heat flux across the left/right boundaries.

When the elements become too distorted with on-going deformation, a remeshing step restores the left boundary to the initial location, effectively adding a new oceanic plate at the left end. The top surface topography is preserved during remeshing. Erosion and sedimentation is implemented with simple surface topography diffusion with a low diffusion coefficient $10^{-6} \mathrm{~m}^{2} \mathrm{~s}^{-1}$.

\section{RESULTS}

We used a setup based on the models of Tan et al. (2012). The friction angle of the sediment and serpentinized peridotite were set to $5^{\circ}$. We varied the mantle wedge serpentinization thickness $H_{\text {serp }}$ from $0-35 \mathrm{~km}$ in the models. We also varied the mantle hydration depth (discussed in section 3.4). In each case, the model was run until the subduction geometry became stable. The resultant petrological structure and flow pattern in the forearc and mantle wedge regions were analysed. The models can be divided into four categories: no stable subduction, thin channel, thick channel, and deep hydration. Models from each category are presented below. The results are plotted with the trenches aligned so that it will be easier to compare slab dips.

\subsection{No Stable Subduction}

Models with thin $H_{\text {serp }}(0-5 \mathrm{~km})$ fail to initiate stable subduction. We presented the model evolution with $H_{\text {serp }}=5 \mathrm{~km}$ (Fig. 2). As the model starts, the oceanic plate is pushed at constant velocity towards the right. A deep thrust develops from the initial weak zone. The oceanic plate plunges along the deep thrust. After 4 Myrs of convergence, the oceanic slab reaches $70 \mathrm{~km}$ depth with a very gentle dip. Temperature and pressure in the slab increase as it is sinking deeper into the mantle. The basaltic crust turns 

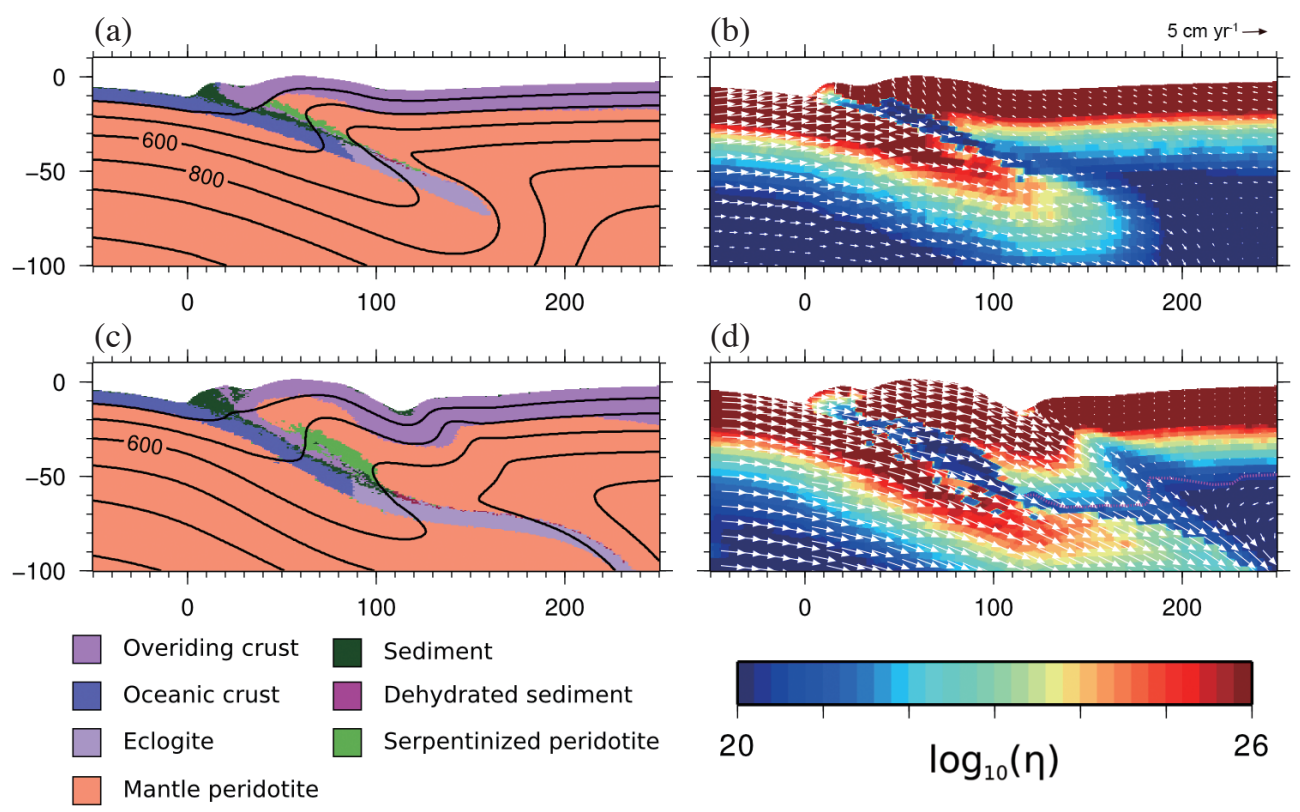

Fig. 2. The evolution of model $H_{\text {serp }}=5 \mathrm{~km}$. The trenches are aligned in the plots. The left columns are plots of the rock types with temperature contours at $200^{\circ} \mathrm{C}$ intervals. The right columns are plots of viscosity in log scale and flow velocity. The pink dashed line marks the continental lithosphere base. (a) - (b) Subduction initiation and buckling of the forearc. (c) - (d) Subduction failed. (Color online only)

into eclogite at around $40 \mathrm{~km}$ depth. A thin layer of serpentinized peridotite forms above the basaltic crust (Fig. 2a). The low viscosity and weak frictional strength of the serpentinite allow the oceanic slab to slide beneath the continental lithosphere. Because basalt dehydration is completed around $40 \mathrm{~km}$, the mantle above the eclogite slab is not serpentinized. As a result, the slab tip is in direct contact with the cold and highly viscous continental lithosphere (Fig. 2b). The slab tip becomes coupled to the continent lithosphere base (pink dashed line) and underthrusts nearly horizontally under it. The forearc region bends and buckles under the compressive stress. The bending creates two sedimentary basins on the forearc region, one $30 \mathrm{~km}$ from the trench and the other $120 \mathrm{~km}$ away from the trench. The stress is concentrated on the basins due to elastic bending and sediment load. The bending amplitude intensifies as the convergence proceeds. After 8 Myrs, the stress exceeds the lithosphere strength. A new deep thrust forms at the deep basin, $115 \mathrm{~km}$ landward from the trench (Figs. 2c, d). At this stage most of the convergence is taken up by the new thrust. Subduction along the original thrust has failed to proceed further. We terminate the model calculation as a result.

Since the horizontal grid spacing $(4 \mathrm{~km})$ is comparable to the serpentinized layer thickness, there is a concern about insufficient resolution. Additional models with refined horizontal grid spacing down to $1.6 \mathrm{~km}$ are performed. The high resolution results show that stable subduction can be achieved with $H_{\text {serp }} \geq 3 \mathrm{~km}$ but not with $H_{\text {serp }}=1.5 \mathrm{~km}$. It appears that the minimum serpentinized layer thickness required to sustain stable subduction is resolution-dependent, which merits future study in greater detail.

\subsection{Thin Channel}

Models with intermediate $H_{\text {serp }}(10-25 \mathrm{~km})$ are sufficient to initiate and sustain stable subduction. The serpentinized peridotite layer is thin and forms a weak interface channel. The material inside the channel is dragged down with the slab. Return flow is non-existent within the channel.

A typical model of this type is $H_{\text {serp }}=25 \mathrm{~km}$ (Fig. 3). The evolution of the first 4 Myrs is similar to that for the previous model. However, the thicker serpentinized peridotite layer decouples the slab from the forearc and allows steeper slab dip (Figs. 3a, b). The slab tip does not encounter strong resistance and can continue to move downward. Subduction can continue as a result.

During 10 to 40 Myrs, the trench keeps advancing landward, while the slab dip remains roughly constant. After 40 Myrs of convergence (Fig. 3c), the slab has a dip of $25^{\circ}$ at shallow depth (between $10-50 \mathrm{~km}$ ) and a dip of $47^{\circ}$ at intermediate depth (between $50-100 \mathrm{~km}$ ). A broad accretionary prism consisting of sediment and former continental forearc is formed. Some sediment is subducted with the slab and transformed into schist at about $70 \mathrm{~km}$ depth. The serpentinized peridotite channel deformation is a simple shear, parallel to the slab dip. There is no significant motion in the direction against the subduction, i.e., no return flow. Under the continental plate, the speed of asthenosphere flow is $\sim 1 \mathrm{~cm} \mathrm{yr}^{-1}$, slower than the subducting slab speed (Fig. 3d). The continental lithosphere thickness is at around 

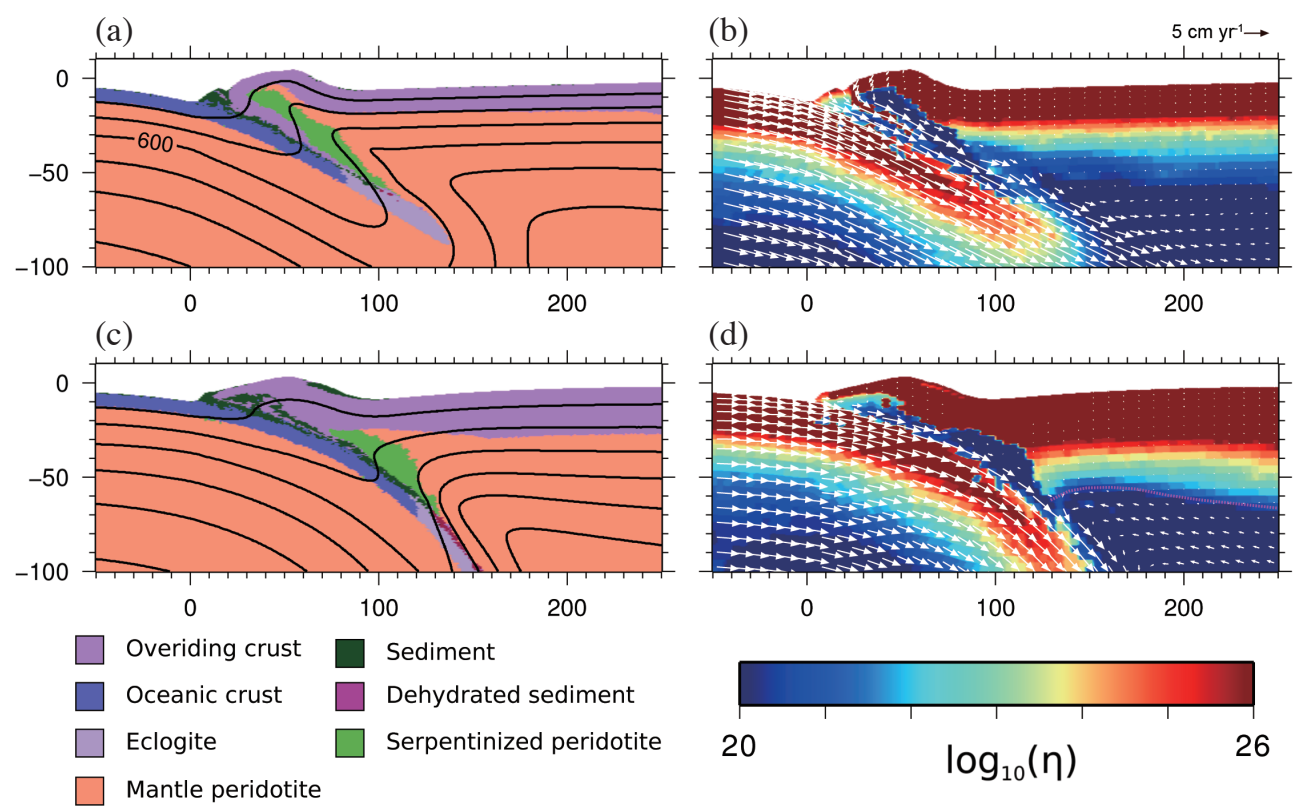

Fig. 3. The evolution of model $H_{\text {serp }}=25 \mathrm{~km}$. (a) - (b) Subduction initiation. (c) - (d) Stable configuration of subduction. (Color online only)

$60 \mathrm{~km}$ depth (pink dashed line). The eclogite transformation starts at $62 \mathrm{~km}$ depth. Most of the serpentinized peridotite is located above $60 \mathrm{~km}$ depth and bounded by the continental lithosphere from the top and right. The top slab surface at $60 \mathrm{~km}$ depth is in close proximity to the continental lithosphere base, indicating the influence of slab suction. A small amount of serpentinized peridotite is carried with the slab to deeper depth before it dehydrates and transforms back into (anhydrous) peridotite, but its effect on the dynamics is negligible.

\subsection{Thick Channel}

Models with thick $H_{\text {serp }}(>25 \mathrm{~km})$ will have a thick serpentinized peridotite layer that is strongly deformed with significant return flow. We present the model evolution with $H_{\text {serp }}=35 \mathrm{~km}$ (Fig. 4). After 4 Myrs of convergence, the slab dip and depth are almost the same as those in model $H_{\text {serp }}=25 \mathrm{~km}$ (Fig. 4a). However, the whole forearc mantle is serpentinized because the forearc mantle thickness is less than $H_{\text {serp }}$. The forearc becomes very weak and deforms severely (Fig. 4b). Significant uplift occurs in the forearc mantle, which raises the $400^{\circ} \mathrm{C}$ isotherm by as much as $20 \mathrm{~km}$. Most of the forearc is later dragged down with the slab as subduction proceeds.

At 12 Myrs the slab dip is very steep, $43^{\circ}$ at shallow depth and almost $60^{\circ}$ at intermediate depth (Fig. 4c). Strong subduction erosion occurs at the forearc base. A big piece of the forearc crust is shaved off from the accretionary prism and sinks with the slab. The serpentinized mantle also moves downward with the slab (Fig. 4d). The mantle wedge is cooled as a result. With the cooled mantle wedge, the slab heats up less. The eclogite transformation is delayed to as deep as $74 \mathrm{~km}$ depth.

After the piece of forearc crust sinks below the bottom boundary, the slab dip starts to stabilize. At $40 \mathrm{Myrs}$, an accretionary prism has formed, whose length and thickness are very similar to the accretionary prism in model $H_{\text {serp }}=25 \mathrm{~km}$. The slab has a dip of $27^{\circ}$ at shallow depth and $47^{\circ}$ at intermediate depth (Fig. 4e), also very similar to the dip in model $H_{\text {serp }}=25 \mathrm{~km}$. The top slab surface at $60 \mathrm{~km}$ depth is still close to the continental lithosphere base (pink dashed line) with very little serpentinized peridotite in between. Most of the serpentinized peridotite is located above $60 \mathrm{~km}$ depth and bounded by the continental lithosphere. This is because eclogite transformation starts at $59 \mathrm{~km}$ depth and mantle serpentinization is absent below this depth.

A trench-ward motion, $\sim 0.5 \mathrm{~cm} \mathrm{yr}^{-1}$ in magnitude, appears on the upper part of the serpentinized mantle wedge (Fig. 4f). An upward motion, $\sim 0.4 \mathrm{~cm} \mathrm{yr}^{-1}$, appears on the right part of the serpentinized mantle wedge. A counterclockwise rotation circulation is established within the serpentinized wedge. However, the circular flow within the serpentinized wedge is separated from the flow under the continental asthenosphere. Material from asthenosphere never flows into the serpentinized wedge.

\subsection{Deep Hydration}

We found that the previous two models $\left(H_{\text {serp }}=25\right.$, $35 \mathrm{~km}$ ) have very similar slab dip, slab temperature and basalt-eclogite transformation depth, which leads to similar down-dip limit in the serpentinized peridotite at around $60 \mathrm{~km}$ depth. Coincidentally, the continental lithosphere 
(a)

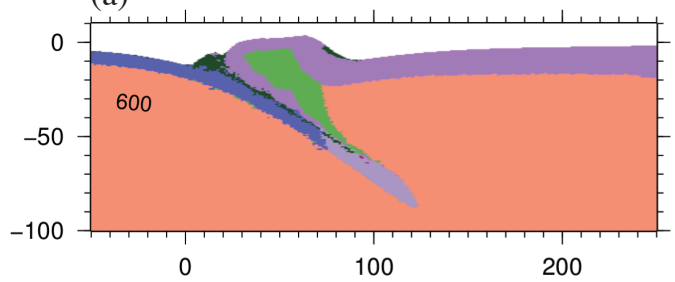

(c)

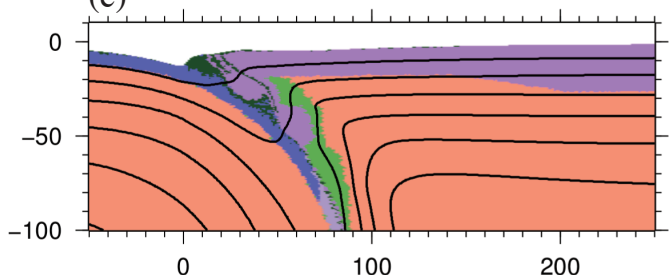

(e)

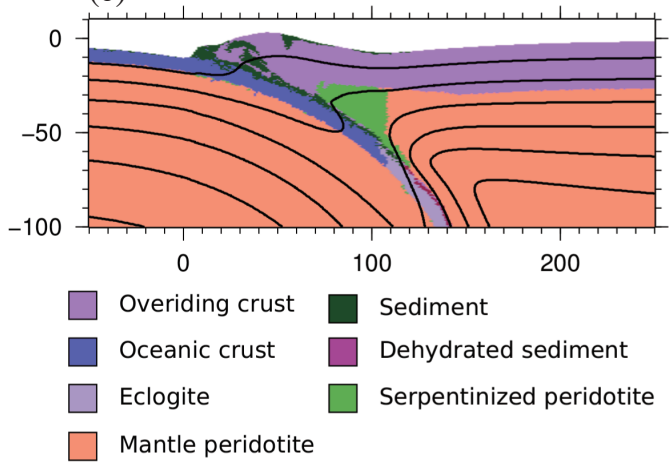

(b) $5 \mathrm{~cm} \mathrm{rr}^{1-3}$

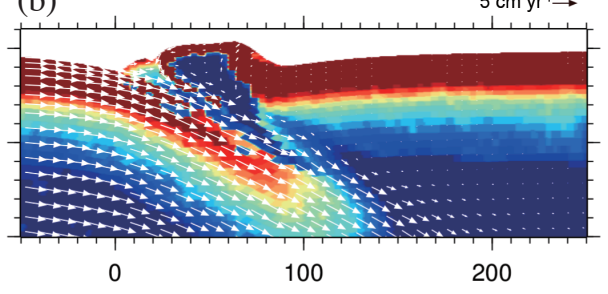

(d)

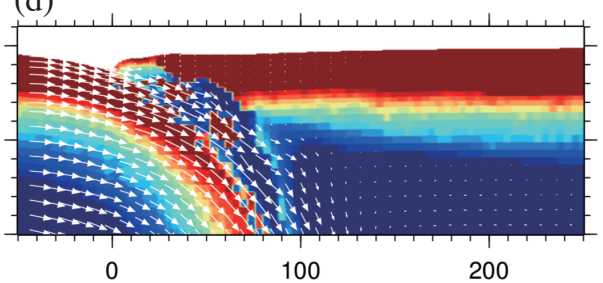

(f)

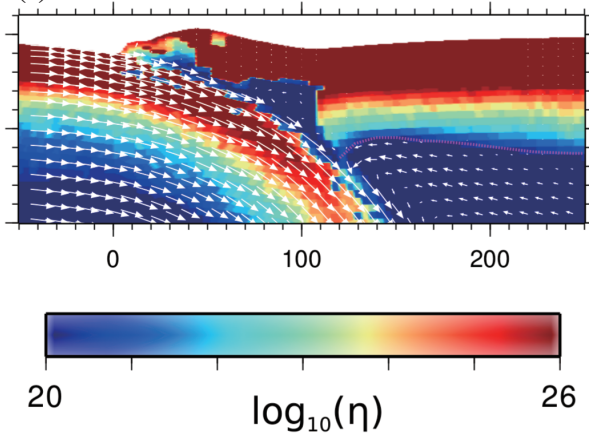

Fig. 4. The evolution of model $H_{\text {serp }}=35 \mathrm{~km}$. (a) - (b) Subduction initiation. (c) - (d) Erosion of forearc crust. (e) - (f) Stable configuration of subduction. (Color online only)

thickness in these models, which is controlled by the initial temperature profile on the continent plate, is also around $60 \mathrm{~km}$. We found that most of the serpentinized mantle is bounded between the continental lithosphere and subduction interface and does not provide enough lubrication between the slab and the continental lithosphere base. If mantle serpentinization continues at deeper depth, how will it affect the slab dip?

To answer this question we extend the down-dip extent of mantle serpentinization. In previous models, we assumed that mantle serpentinization stops once the basalt-eclogite transformation is completed. However, an additional water source can be provided by the dehydration of hydrous minerals in the oceanic mantle lithosphere. Seismic exploration has found evidence of serpentinite under the oceanic Moho in the Central America subduction zone (Van Avendonk et al. 2011). The sub-Moho serpentinite is subjected to less heating and remains stable at greater depth. The sub-Moho serpentinite dehydration could provide water for deeper mantle hydration (Angiboust et al. 2012). In another series of models, we extended the mantle serpentinization depth to $25 \mathrm{~km}$ below the basalt-eclogite transformation boundary. This series of models will be termed deep hydration model to distinguish from the previous normal hydration models.
The effect of deeper extent of hydration on the slab dip is noticeable. In the deep hydration model $H_{\text {serp }}=25$, the slab dip becomes $31^{\circ}$ at shallow depth and $49^{\circ}$ at intermediate depth (Figs. 5a, b). The accretionary prism size is smaller, compared with that in the normal hydration model $H_{\text {serp }}=25$ (Fig. 3c). The slab bending is more pronounced due to reduced coupling between the slab and overlying mantle. In the deep hydration model $H_{\text {serp }}=35$, the slab dip further increases to $35^{\circ}$ at shallow depth and $54^{\circ}$ at intermediate depth (Figs. 5c, d). The steep slab dip shortens the subduction interface between the two plates. The serpentinized mantle wedge goes down deeper than the continental lithosphere base. The serpentinized wedge acts as a broad shear zone, fully decoupling the slab from the continental lithosphere and asthenosphere. Consequently, most of the drag stress between the two plates is concentrated on the forearc prism. As a result, strong subduction erosion occurs in this model. The forearc crust is continuously scraped off and carried down with the slab. No internal circulation exists within the serpentinized mantle wedge.

\section{DISCUSSION}

Four models $\left(H_{\text {serp }}=10,15,20,25 \mathrm{~km}\right)$ in our study 
(a)
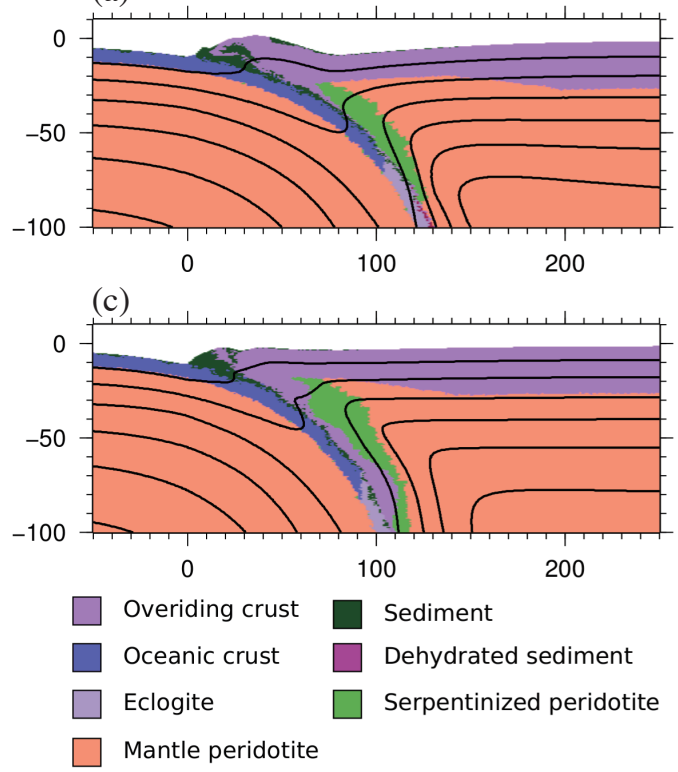

(b) $5 \mathrm{~cm} \mathrm{yr} \rightarrow$

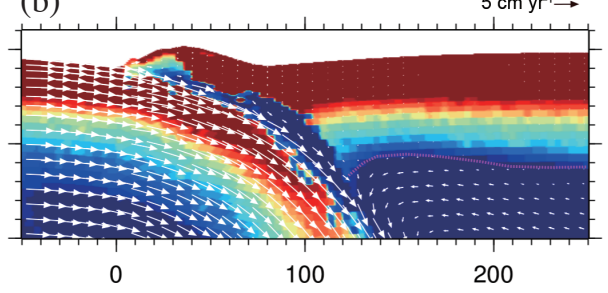

(d)

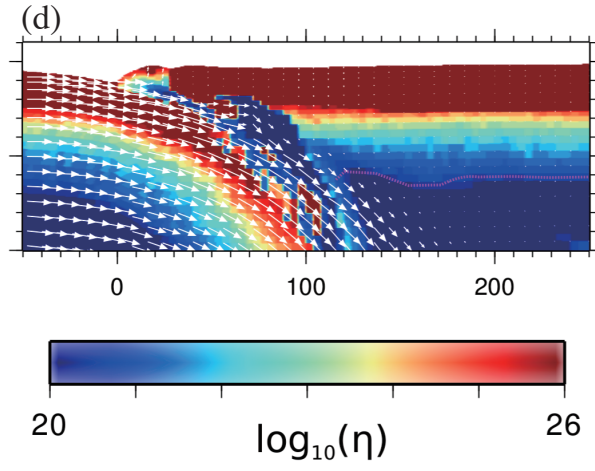

Fig. 5. The deep hydration models. (a) - (b) Stable configuration of subduction of model $H_{\text {serp }}=25 \mathrm{~km}$. (a) - (b) Stable configuration of subduction of model $H_{\text {serp }}=35 \mathrm{~km}$. (Color online only)

belong to the "thin channel" category, and two models $\left(H_{\text {serp }}=30,35 \mathrm{~km}\right)$ to the "thick channel" category. The slab dip angles at shallow depth (between $10-50 \mathrm{~km}$ ) and at intermediate depth (between $50-100 \mathrm{~km}$ ) are measured (Fig. 6). The slab dips in these models are always $24-27^{\circ}$ at shallow depth and $44-47^{\circ}$ at intermediate depth regardless of $H_{\text {serp }}$ for the normal hydration models. We found no systematic variation in slab dips in these models. Despite expanding the parameter range of $H_{\text {serp }}$ from $15-25 \mathrm{~km}$ used by Tan et al. (2012) to $10-35 \mathrm{~km}$ used in this study, our results did not deviate from the conclusion of Tan et al. (2012). The slab dip is indeed insensitive to the value of $H_{\text {serp }}$ in this specific model configuration.

We investigated the reason for this insensitivity through a new set of models with deeper hydration. We noticed that in the normal hydration models the down-dip serpentinization limit (controlled by the eclogite transformation) occurs at around $60 \mathrm{~km}$ depth, which is also the thickness of the overriding continental lithosphere in these models. In a new set of models, we extended the serpentinization to deeper depth. Within the deep hydration models, we found a positive correlation between the slab dip and $H_{\text {serp }}$ (Fig. 6). The slab dip of a deep hydration model is also larger than that in the corresponding normal hydration model.

Comparing the deep and normal hydration models, we found that the slab dip is affected by the depth extent and mantle serpentinization thickness. However, the effect is not simple. There is a critical depth determined by the overriding lithosphere thickness on the down-dip mantle serpentinization extent. If the down-dip mantle serpentinization extent does not exceed the critical depth, the amount of ser- pentinized peridotite at this depth is not enough to separate the slab from the overriding lithosphere base. As a result, the slab is partially coupled to the overriding lithosphere and has a constant dip angle regardless of the mantle serpentinization thickness. However, if the down-dip mantle serpentinization extent exceeds the critical depth, the slab and the overriding lithosphere base would be separated and decoupled by a thick layer of serpentinized peridotite. This allows further slab bending and results in steeper slab dip.

In the Tan et al. (2012) high friction models, they found that a thicker serpentinized peridotite layer will increase the slab dip. The overriding lithosphere thickness in their models was $60 \mathrm{~km}$, the same as used in this study. In their high friction models ( $\phi=15^{\circ}$ in Fig. 8 of Tan et al. 2012), the slabs subduct with a large dip angle and are colder than the slabs in low friction models. The basalt-eclogite transformation depth is thus delayed to deeper depth, and indeed exceeds $60 \mathrm{~km}$ depth. The resultant deep hydration generates the observed positive correlation between the slab dip and $H_{\text {serp }}$.

In thin channel models, the lower serpentinized wedge part is coupled with the slab and moves downward with it, while the upper serpentinized wedge part stays stagnant. In thick channel models, the whole serpentinized wedge deforms with a counter-clockwise rotation. Serpentinized peridotite from as deep as $50 \mathrm{~km}$ can be brought upward to $30 \mathrm{~km}$ depth by this rotational motion (Fig. 4f). The upward migration is slow, on the order of $0.4 \mathrm{~cm} \mathrm{yr}^{-1}$, but its significance cannot be overlooked. This is the only uplifting region inside the mantle wedge. If this region is later exhumed and exposed to the surface, its P-T-t path will record 


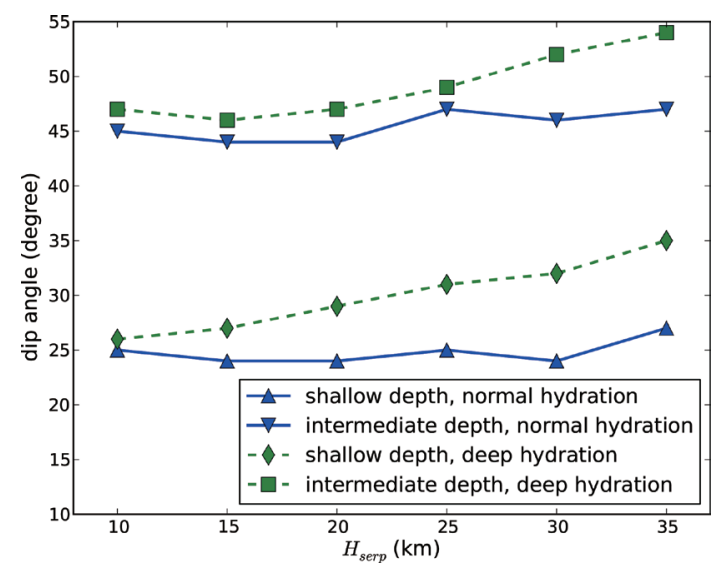

Fig. 6. Variation of slab dips at shallow and intermediate depths as a function of the serpentinized mantle thickness. (Color online only)

retrograde metamorphism prior to the final exhumation. Its geological implication warrants further study.

In all models with stable subduction, the serpentinized mantle does not participate with the corner flow in the mantle wedge. There is no material flowing from the asthenosphere into the serpentinized mantle wedge. As a result, the temperature in the wedge remains low and is always within the serpentinite stability field. This is consistent with the result of Wada et al. (2008). They found that strong flow from the asthenosphere into the mantle wedge tip only happens when the slab and mantle wedge are fully coupled. In our models, a serpentinized peridotite layer always exists between the slab and mantle wedge and mechanically decouples them.

We found that mantle serpentinization is important to subduction, at least for the initial configuration in our models. Without a sufficient amount of serpentinized peridotite to lubricate the whole subduction interface, the resultant resistance stress would increase with time and eventually exceed the overriding plate strength. As a result, a new thrust will develop and break the plate. Further convergence will be accommodated by the new thrust, and subduction on the original trench will cease. Based on the low serpentine antigorite viscosity, Hilairet et al. (2007) proposed that a serpentinized fault might be required for subduction initiation. Our results support their conjecture. We found that a thin layer of serpentinization mantle is required for stable subduction. However, our results cannot be used to constrain the minimum serpentinization thickness in an established subduction zone. The resistive stress is highest during the first 5 Myrs of subduction initiation. After the subduction is established the resistive stress is greatly reduced (Hall et al. 2003). It is possible that, after successful subduction initiation a thinner serpentinization thickness would be enough to sustain further subduction.

\section{CONCLUSION}

With numerical elasto-visco-plastic models, we investigated the role of the amount of mantel serpentinization on subduction zone evolution. We found that mantle serpentinization is important for subduction. Serpentinized mantle is required to facilitate stable subduction. We found that the slab dip is affected by the down-dip extent and mantle serpentinization thickness. When the serpentinized mantle wedge does not extend below the continental lithosphere base, the amount of serpentinization does not affect the slab dip. In contrast, when the serpentinized mantle wedge is deeper than the continental lithosphere base a thicker serpentinized mantle layer will increase the slab dip.

Acknowledgements We are grateful to the editor RueyJuin Rau and three Anonymous Reviewers for their constructive comments. This work is supported by MOST grant 104-2116-M-001-026 and AS grant AS-104-TP-A04.

\section{REFERENCES}

Angiboust, S., S. Wolf, E. Burov, P. Agard, and P. Yamato, 2012: Effect of fluid circulation on subduction interface tectonic processes: Insights from thermo-mechanical numerical modelling. Earth Planet. Sci. Lett., 357-358, 238-248, doi: 10.1016/j.eps1.2012.09.012. [Link]

Arcay, D., E. Tric, and M. P. Doin, 2005: Numerical simulations of subduction zones: Effect of slab dehydration on the mantle wedge dynamics. Phys. Earth Planet. Inter., 149, 133-153, doi: 10.1016/j.pepi.2004.08.020. [Link]

Billen, M. I. and M. Gurnis, 2001: A low viscosity wedge in subduction zones. Earth Planet. Sci. Lett., 193, $227-$ 236, doi: 10.1016/S0012-821X(01)00482-4. [Link]

Blakely, R. J., T. M. Brocher, and R. E. Wells, 2005: Subduction-zone magnetic anomalies and implications for hydrated forearc mantle. Geology, 33, 445-448, doi: 10.1130/G21447.1. [Link]

Bostock, M. G., R. D. Hyndman, S. Rondenay, and S. M. 
Peacock, 2002: An inverted continental Moho and serpentinization of the forearc mantle. Nature, 417, 536538, doi: 10.1038/417536a. [Link]

Chen, Y. and W. J. Morgan, 1990: A nonlinear rheology model for mid-ocean ridge axis topography. J. Geophys. Res., 95, 17583-17604, doi: 10.1029/ JB095iB11p17583. [Link]

Chou, H. C., B. Y. Kuo, L. Y. Chiao, D. Zhao, and S. H. Hung, 2009: Tomography of the westernmost Ryukyu subduction zone and the serpentinization of the forearc mantle. J. Geophys. Res., 114, B12301, doi: 10.1029/2008JB006192. [Link]

Conrad, C. P. and C. Lithgow-Bertelloni, 2002: How Mantle Slabs Drive Plate Tectonics. Science, 298, 207-209, doi: 10.1126/science.1074161. [Link]

Cundall, P. A., 1989: Numerical experiments on localization in frictional materials. Ing. Arch., 59, 148-159, doi: 10.1007/BF00538368. [Link]

Dahlen, F. A., J. Suppe, and D. Davis, 1984: Mechanics of fold-and-thrust belts and accretionary wedges: Cohesive Coulomb Theory. J. Geophys. Res., 89, 1008710101, doi: 10.1029/JB089iB12p10087. [Link]

Escartín, J., G. Hirth, and B. Evans, 2001: Strength of slightly serpentinized peridotites: Implications for the tectonics of oceanic lithosphere. Geology, 29, 10231026, doi: 10.1130/0091-7613(2001)029<1023:SOSS$\mathrm{PI}>2.0 . \mathrm{CO} ; 2$. [Link]

Faccenda, M., T. V. Gerya, and L. Burlini, 2009: Deep slab hydration induced by bending-related variations in tectonic pressure. Nat. Geosci., 2, 790-793, doi: 10.1038/ ngeo656. [Link]

Forsyth, D. and S. Uyeda, 1975: On the relative importance of the driving forces of plate motion. Geophys. J. Int., 43, 163-200, doi: 10.1111/j.1365-246X.1975. tb00631.x. [Link]

Gerya, T. V. and F. I. Meilick, 2011: Geodynamic regimes of subduction under an active margin: Effects of rheological weakening by fluids and melts. $J$. Metamorph. Geol., 29, 7-31, doi: 10.1111/j.15251314.2010.00904.x. [Link]

Gerya, T. V. and D. A. Yuen, 2003: Rayleigh-Taylor instabilities from hydration and melting propel 'cold plumes' at subduction zones. Earth Planet. Sci. Lett., 212, 4762, doi: 10.1016/S0012-821X(03)00265-6. [Link]

Gorczyk, W., A. P. Willner, T. V. Gerya, J. A. D. Connolly, and J. P. Burg, 2007: Physical controls of magmatic productivity at Pacific-type convergent margins: Numerical modelling. Phys. Earth Planet. Inter., 163, 209-232, doi: 10.1016/j.pepi.2007.05.010. [Link]

Gurnis, M., C. Hall, and L. Lavier, 2004: Evolving force balance during incipient subduction. Geochem. Geophys. Geosyst., 5, Q07001, doi: 10.1029/2003GC000681. [Link]

Hacker, B. R., 1996: Eclogite formation and the rheology, buoyancy, seismicity, and $\mathrm{H}_{2} \mathrm{O}$ content of oceanic crust. In: Bebout, G. E., D. W. Scholl, S. H. Kirby, and J. P. Platt (Eds.), Subduction Top to Bottom, American Geophysical Union, Washington, D. C., 337-346, doi: 10.1029/GM096p0337. [Link]

Hacker, B. R., G. A. Abers, and S. M. Peacock, 2003: Subduction factory 1 . Theoretical mineralogy, densities, seismic wave speeds, and $\mathrm{H}_{2} \mathrm{O}$ contents. J. Geophys. Res., 108, doi: 10.1029/2001JB001127. [Link]

Hall, C. E., M. Gurnis, M. Sdrolias, L. L. Lavier, and R. D. Müller, 2003: Catastrophic initiation of subduction following forced convergence across fracture zones. Earth Planet. Sci. Lett., 212, 15-30, doi: 10.1016/ S0012-821X(03)00242-5. [Link]

Hassani, R., D. Jongmans, and J. Chéry, 1997: Study of plate deformation and stress in subduction processes using two-dimensional numerical models. J. Geophys. Res., 102, 17951-17965, doi: 10.1029/97JB01354. [Link]

Heuret, A., S. Lallemand, F. Funiciello, C. Piromallo, and C. Faccenna, 2011: Physical characteristics of subduction interface type seismogenic zones revisited. Geochem. Geophys. Geosyst., 12, Q01004, doi: 10.1029/2010GC003230. [Link]

Hilairet, N., B. Reynard, Y. Wang, I. Daniel, S. Merkel, N. Nishiyama, and S. Petitgirard, 2007: High-pressure creep of serpentine, interseismic deformation, and initiation of subduction. Science, 318, 1910-1913, doi: 10.1126/science.1148494. [Link]

Hyndman, R. D. and S. M. Peacock, 2003: Serpentinization of the forearc mantle. Earth Planet. Sci.Lett., 212, 417432, doi: 10.1016/S0012-821X(03)00263-2. [Link]

Iwamori, H., C. Richardson, and S. Maruyama, 2007: Numerical modeling of thermal structure, circulation of $\mathrm{H}_{2} \mathrm{O}$, and magmatism-metamorphism in subduction zones: Implications for evolution of arcs. Gondwana Res., 11, 109-119, doi: 10.1016/j.gr.2006.04.010. [Link]

Jarrard, R. D., 1986: Relations among subduction parameters. Rev. Geophys., 24, 217-284, doi: 10.1029/ RG024i002p00217. [Link]

Kaus, B. J. P., C. Steedman, and T. W. Becker, 2008: From passive continental margin to mountain belt: Insights from analytical and numerical models and application to Taiwan. Phys. Earth Planet. Inter., 171, 235-251, doi: 10.1016/j.pepi.2008.06.015. [Link]

Kirby, S. H. and A. K. Kronenberg, 1987: Rheology of the lithosphere: Selected topics. Rev. Geophys., 25, 12191244, doi: 10.1029/RG025i006p01219. [Link]

Lallemand, S., A. Heuret, and D. Boutelier, 2005: On the relationships between slab dip, back-arc stress, upper plate absolute motion, and crustal nature in subduction zones. Geochem. Geophys. Geosyst., 6, Q09006, doi: 10.1029/2005GC000917. [Link]

Lavier, L. L., W. R. Buck, and A. N. B. Poliakov, 2000: Factors controlling normal fault offset in an ideal 
brittle layer. J. Geophys. Res., 105, 23431-23442, doi: 10.1029/2000JB900108. [Link]

Manea, V. C., M. Manea, V. Kostoglodov, and G. Sewell, 2005: Thermo-mechanical model of the mantle wedge in Central Mexican subduction zone and a blob tracing approach for the magma transport. Phys. Earth Planet. Inter., 149, 165-186, doi: 10.1016/j.pepi.2004.08.024. [Link]

Nichols, G. T., P. J. Wyllie, and C. R. Stern, 1994: Subduction zone melting of pelagic sediments constrained by melting experiments. Nature, 371, 785-788, doi: 10.1038/371785a0. [Link]

Nikulin, A., V. Levin, and J. Park, 2009: Receiver function study of the Cascadia megathrust: Evidence for localized serpentinization. Geochem. Geophys. Geosyst., 10, Q07004, doi: 10.1029/2009GC002376. [Link]

Peacock, S. M., 1996: Thermal and petrologic structure of subduction zones. In: Bebout, G. E., D. W. Scholl, S. H. Kirby, and J. P. Platt (Eds.), Subduction Top to Bottom, American Geophysical Union, Washington, D. C., 119-133, doi: 10.1029/GM096p0119. [Link]

Poliakov, A. N. B., P. A. Cundall, Y. Y. Podladchikov, and V. A. Lyakhovsky, 1993: An explicit inertial method for the simulation of viscoelastic flow: An evaluation of elastic effects on diapiric flow in two- and threelayers models. In: Stone, David B. and S. K. Runcorn (Eds.), Flow and Creep in the Solar System: Observations, Modeling and Theory, Springer Netherlands, Netherlands, 175-195, doi: 10.1007/978-94-015-82063_12. [Link]

Ramachandran, K., S. E. Dosso, G. D. Spence, R. D. Hyndman, and T. M. Brocher, 2005: Forearc structure beneath southwestern British Columbia: A three-dimensional tomographic velocity model. J. Geophys. Res., 110, B02303, doi: 10.1029/2004JB003258. [Link]

Ranalli, G., 1995: Rheology of the Earth, Springer Netherlands, Netherlands, $414 \mathrm{pp}$.

Sobolev, S. V. and A. Y. Babeyko, 2005: What drives orogeny in the Andes? Geology, 33, 617-620, doi: 10.1130/ G21557AR.1. [Link]

Suppe, J., 1981: Mechanics of mountain building and metamorphism in Taiwan. Mem. Geol. Soc. China, 4, 67-89.

Syracuse, E. M. and G. A. Abers, 2006: Global compilation of variations in slab depth beneath arc volcanoes and implications. Geochem. Geophys. Geosyst., 7, Q05017, doi: 10.1029/2005GC001045. [Link]

Tan, E., L. L. Lavier, H. J. A. Van Avendonk, and A. Heuret, 2012: The role of frictional strength on plate coupling at the subduction interface. Geochem. Geophys. Geosyst., 13, Q10006, doi: 10.1029/2012GC004214. [Link]

Tibi, R., D. A. Wiens, and X. Yuan, 2008: Seismic evidence for widespread serpentinized forearc mantle along the Mariana convergence margin. Geophys. Res. Lett., 35, L13303, doi: 10.1029/2008GL034163. [Link]

Tovish, A., G. Schubert, and B. P. Luyendyk, 1978: Mantle flow pressure and the angle of subduction: Non-Newtonian corner flows. J. Geophys. Res., 83, 5892-5898, doi: 10.1029/JB083iB12p05892. [Link]

Ulmer, P. and V. Trommsdorff, 1995: Serpentine stability to mantle depths and subduction-related magmatism. Science, 268, 858-861, doi: 10.1126/science.268.5212.858. [Link]

Van Avendonk, H. J. A., W. S. Holbrook, D. Lizarralde, and P. Denyer, 2011: Structure and serpentinization of the subducting Cocos plate offshore Nicaragua and Costa Rica. Geochem. Geophys. Geosyst., 12, Q06009, doi: 10.1029/2011GC003592. [Link]

Van Keken, P. E., 2003: The structure and dynamics of the mantle wedge. Earth Planet. Sci. Lett., 215, 323-338, doi: 10.1016/S0012-821X(03)00460-6. [Link]

Van Keken, P. E. and S. D. King, 2005: Thermal structure and dynamics of subduction zones: Insights from observations and modeling. Phys. Earth Planet. Inter., 149, 1-6, doi: 10.1016/j.pepi.2004.10.001. [Link]

Wada, I., K. Wang, J. He, and R. D. Hyndman, 2008: Weakening of the subduction interface and its effects on surface heat flow, slab dehydration, and mantle wedge serpentinization. J. Geophys. Res., 113, B04402, doi: 10.1029/2007JB005190. [Link]

Yamamoto, Y., K. Obana, T. Takahashi, A. Nakanishi, S. Kodaira, and Y. Kaneda, 2013: Imaging of the subducted Kyushu-Palau Ridge in the Hyuga-nada region, western Nankai Trough subduction zone. Tectonophysics, 589, 90-102, doi: 10.1016/j.tecto.2012.12.028. [Link] 